\title{
技術 報 告
}

\section{電離真空計の電子電流安定化回路ならびに フィラメント保護回路*}

\author{
長 井一 敏** \\ (昭和 45 年 2 月 13 日受理)
}

An Electron Emission Regulator and a Filament Protector for an Ionization Gauge

\section{Kazutoshi NAGAI}

(The Institute of Physical and Chemical Research, Yamatomachi, Saitama, JAPAN)

(Received Feb. 13. 1970)

A transistorized electron emission regulator and a transistorized filament protector for an ionization gauge have been studied. This electron emission regulator having a current path from filament of the ionization gauge to ground through base-emitter junction of a transistor, electron emission current of the gauge modulates the collector current of the transistor, and this modulated collector current regulates the heating current for the gauge filament. On the other hand, this filament protector is a type to detect voltage increase across the filament when vacuum pressure increases. These circuits are smallsized, of light weight and inexpensive, and moreover are seldom out of order because they are very simple.

1. 序

電離真空計や電子顕微鏡の電子除, 西るいは質量分析 計の電子衝撃型イオン源等, 劣よそ真空中で電子流を扱 ら装置では, 電子電流の安定化を計ることと, 真空度の 低下に起因するフィラメントの消耗を防ぎ保護すること は, ともに重要な要素であって, 種々の方式の回路が考 案されている。

電子電流の安定化には, 真空管を使用した RidenourLampsonの回路1が有名であり，さらに簡単な回路2も 発表されているが，最近はトランジスタ一を用いた安定 化回路が多く使われている3). またフィラメントの保護 回路としては, 従来, 真空度の低下にともなうイオン電流 の增加を検知して, フィラメントが酸化消耗するのを防 ぐす法がとられてきたが, 新しい陚みとしてフィラメン 卜加熱電流の増加を検知する力法年が提案さ机ている。

筆者も電離真空診に使用すべく, トランジスターを用 いた電子電流安定化回路5)と，フィラメント加熱電压の 上昇を検知する方式のフィラメント保護回路を試作した ので，以下，その特性について述べる。なお，こ北らの 回路の製作目的は, 構成が単純で故障が少く, 小型軽量 で動作範囲の広い回路を試作することであった。

* 昭和44年11月25日 第10回真空飞関する連侖講演全で一部分護演

***理化学研究所

\section{2. 電子電流安定化回路}

\section{1 安定化回路 I}

Fig. 1 洋陚作した電子電流安定化回路の基本的な回路 である. 安定化すべき電子電流 $I_{b}$ は電離真空計の集電

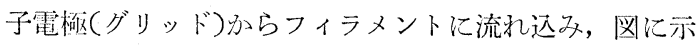
した径路でトランジスター $T_{1}$ のベースを通っててース に落ちる。これにより,トランジスター $T_{1}$ には $\beta_{1} \cdot I_{b}$ の コレクター電流が流れ抵抗 $r_{2}$ の両端に $\beta_{1} \cdot I_{b} \cdot r_{2}$ なる 電位差党生ずる。電源 $P_{1}$ は交流 $50 \mathrm{~Hz}$ 它全波整流した もので, その出力電压 $E_{0}$ と抵抗 $r_{2}$ の両端電生 $\beta_{1} \cdot I_{b}$. $r_{2}$ の差 $\left(E_{0}-\beta_{1} \cdot I_{b} \cdot r_{2}\right)$ でトランジスター $T_{2}, T_{2}$ 安駆 動して電離真空計のフィラメント加熱電流 $I_{c}$ を制御 している。いま何らかの原因で $I_{b}$ が增加（あるい注 隇少)すると, $\left(E_{0}-\hat{\beta}_{1} \cdot I_{b} \cdot r_{2}\right)$ の做が減少（あるい 潽加）し，そのために $I_{\boldsymbol{c}}$ が押光られて $I_{b}$ を元の值 に引㞔し安定化を計かる和けである。な拉，集イオン電 極（プレート）に与えるバイアス電圧（約 $-25 \mathrm{~V})$ には トランジスター $T_{1}$ のベース回路に抵抗 $R$ を挿入し $I_{b}$ に よって生ずる電位差 $R \cdot I_{b}$ を用いている.

電子電流 $I_{b}$ とフィラメント加熱電流 $\boldsymbol{I}_{c}$ との関倸它 各トランジスターのエミッター接地電流増巾率 $\beta_{1}, \beta_{2}$, 降空用いて書き表わせば， 


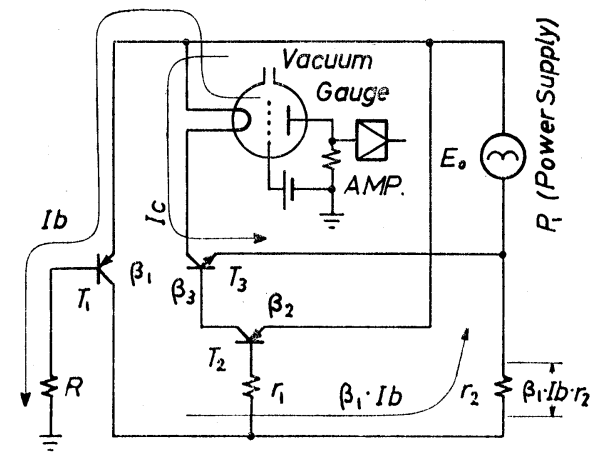

Fig. 1 Fundamental circuit of regulator I. $P_{1}$ is a single-phase full-wave rectified power supply.

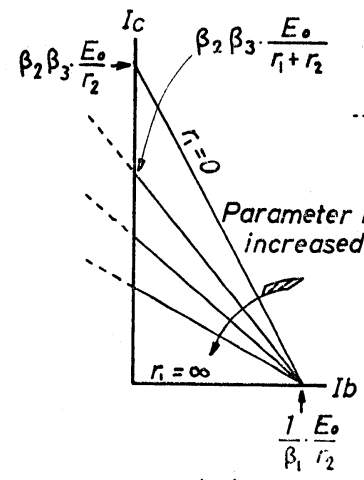

(a)

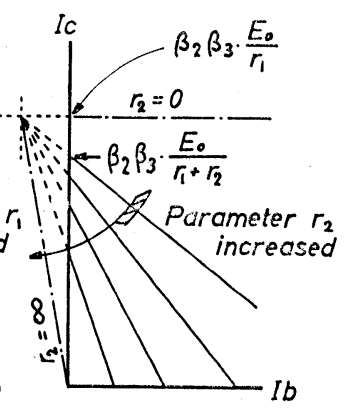

(b)
Fig. 2 Filament current $I_{c}$ vs. electron current $I_{b}$ characteristics fo the regulator (according to the equation (1)) . (a) With $r_{1}$ as a parameter. (b) With $r_{2}$ as a parameter.

$$
I_{c}=\frac{\beta_{1} \cdot \beta_{2} \cdot \beta_{3}}{1+\frac{r_{1}}{r_{2}}}\left(\frac{E_{0}}{r_{2} \beta_{1}}-I_{b}\right) \ldots \ldots
$$

となり， $I_{b}$ の変動に刘する回路の感度は， $\Delta I_{c} / \Delta I_{b}=$ $-\beta_{1} \cdot \beta_{2} \cdot \beta_{3} /\left(1+r_{1} / r_{2}\right)$ で与えられる。 $\beta_{1}, \beta_{2}, \beta_{3}$ が备 トランジスターのコレクター電流の大きさに関係なく一 定ならぼ(1)式注 Fig. 2(a), (b)に示すような直線となる. $r_{2}$ 学固定し $r_{1}$ 学パラメーターとして变化させれば (a)図 となり， $r_{1}$ 学固定して $r_{2}$ をパラメーターとすれば(b)図 のようになる。したがって $r_{1}, r_{2}$ のどちらか一方を調節 することによって $I_{b}$ の值它任意に設定することができ る. しかし同時に感度 $\Delta I_{c} / \Delta I_{b}$ も変化してしまうのが, この方式の一つの点でもある. 一般に $\beta_{1}, \beta_{2}, \beta_{3}$ は二 レクター電流の関数であって一定ではないから, 後で述 ベるように $I_{b}$ と $I_{c}$ の関係は直線とはならないが，回路 定数を沈めるための目安として(1)式を利用亦ることがで きる。

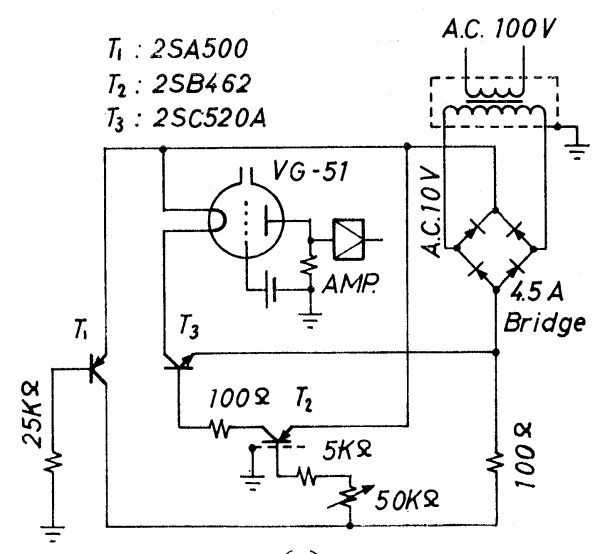

(a)

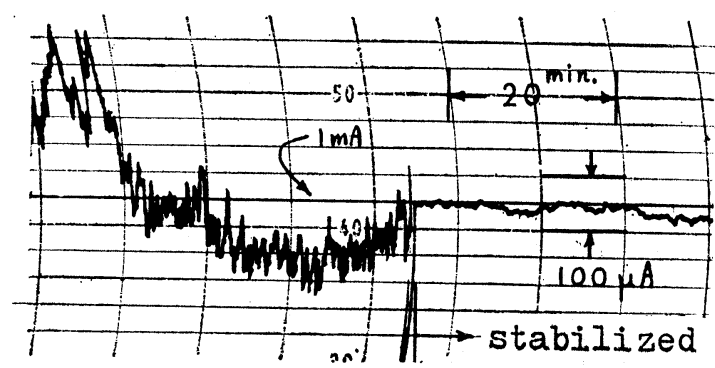

(b)

Fig. 3 (a) Practical circuit of regulator $I$. (b) An example of its dynamics.

回路定数に適当な值索入秃た具体的な回路学Fig. 3 (a) に示し，乙の安定化回路の動作例老（b)に示した。電離 真空計は少タ古い夕イプのもので, VG-51 ( $E_{g}=150 \mathrm{~V}$, $\left.E_{c}=-25 \mathrm{~V}, S=10\right)$ 丧使用し，抵抗 $r_{1}$ 学調節して電子 電流を $1 \mathrm{~mA}$ 亿設定した. (b)図の示すよらに, 管定化し ない場合の電子電流の変動は $0.5 \mathrm{~mA}$ におよぶが, 安定

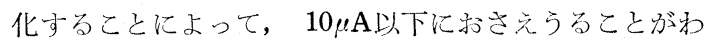
かる。

\section{2 誤差}

Fig.1 ないしはFig.3(a)に示した安定化回路 I では, 電子電流 $I_{b}$ 莸フィラメントの一方の端から取出してい るために，フィラメントの中点の電位が電源電圧の脈動 に従って変動しているはずである. Fig.3(a) の回路で, 真空度 $1 \times 10^{-5}$ Torr程度のとき, フィラメント中点の電 位变動を実測すると約 $3.5 \mathrm{~V}(\mathrm{p}-\mathrm{p})$ であった。これは, 相対的にグリッドの電位が $3.5 \mathrm{~V}$ 程度ゆらいでいること に相当し, 真空度の指示に誤差の入ることが考えられ る。その誤差の大きさを見積るために，グリッド電位の 変動に起因古るイオン電流の変動の様子を調べたのが Fig.4(a)である.（b)法との測定回路である.つまり，電 離真空計 VG-51 では, グリッド電位 $E_{g}$ を $150 \mathrm{~V}$ を中 

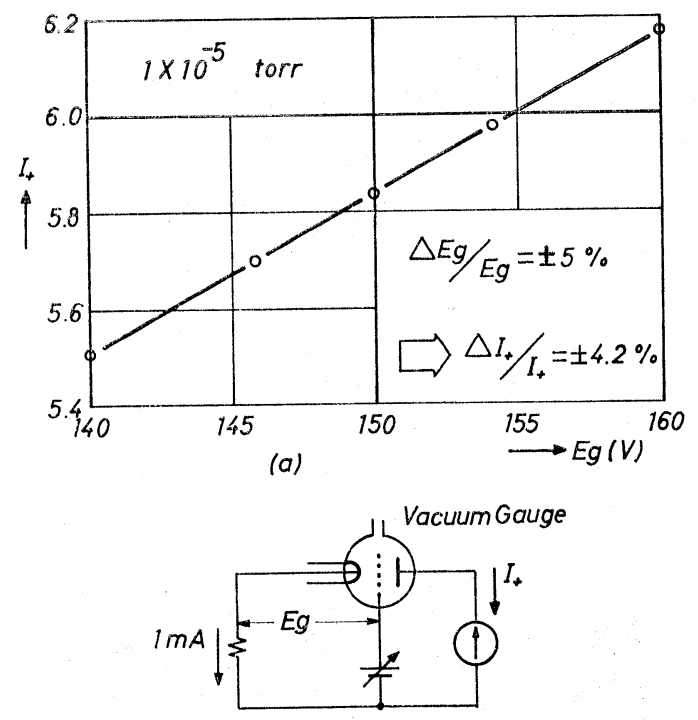

(b)

Fig. 4 (a) Electron collector voltage $E_{g}$ vs. ion current $I_{+}$characteristics for ionization gauhe VG-51. (b) Measuring circuit for this characteristics.

心に $\pm 5 \%$ 変化すると, イオン電流 $I_{+}$はほぼ直線的に 土4.2\%変化することがわかった，先に述べたように実 測によると， $E_{g}$ の变動は 約 $3.5 \mathrm{~V}$ であるから, これ觉 $I_{+}$の変動飞換算すると約 $2 \%$ になる。つまり，Fig. 3 (a) の回路では真空度の指示に $2 \%$ 程度の誤差が入ることに なる。乙かし電離真空計の感度のバラッキ, あるい滇 空度指示用メーターの許容誤差等を考慮すれば, 電離真 空計を通常の便用方法で使っているかぎり，この $2 \%$ と いら誤差は真空度測定上それほど大きな障害にはならな いと思和机るから, Fig. 3(a)の回路注充分, 実用にな るものと考元られる。な礼，ここに述べた誤差の見積り はVG一51亿関するものであるが，他の電離真空計を使 用した場合でも似たような事情であるうと想像される。

\section{3 安定化回路 II}

前述の回路では, 電子電流をフィラメントの一端から 取出したために, 僅少とはいえ, 真空度の指示に誤差の 入ることがわかった，その誤差を除くために，フィラメ ントの中点から電子電流を取出すように改良したものの 基本的な回路をFig. 5 に示した. この回路は全波整流さ れた電源 $P_{1}$ の他に, $50 \mathrm{~Hz}$ 交流電源 $P_{2}$ を備えた二電源 方式である. 電子電流は, 並列抵抗によってフィラメン トの中点から取出され, 変調器に送られて電源 $P_{2}$ の 50 $\mathrm{H}_{\mathrm{z}}$ 交流を振巾变調する. 被变調波は变成器 $\tau_{1}$ を介して トランジスター $T_{1}, T_{2}, T_{3}$ より成る制御回路に戻され

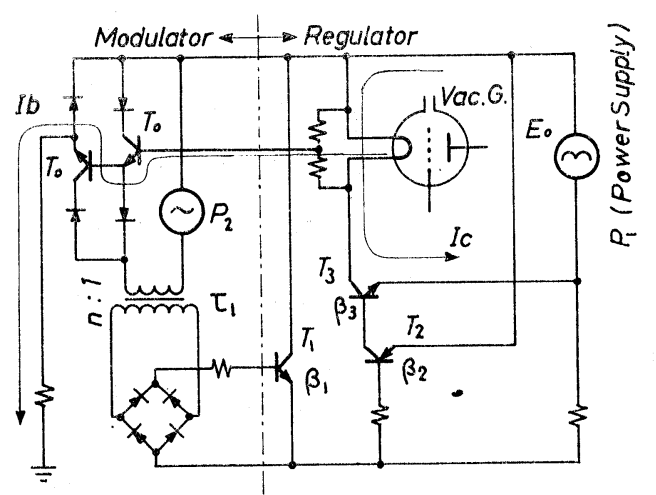

Fig. 5 Fundamental circuit of regulator II. $P_{1}$ is a single $=$ Phase full-wave rectified power supply, and $\mathrm{P}_{2}$ is a single-phase A-C power supply.

\section{$D_{0}: 1 S 184 \quad D_{1}: S H-1 \quad T_{0}, T_{1}: 2 S C 142$ \\ $T_{2}: 2 S B 462 \quad T_{3}: 2 S C 520 \mathrm{~A}$}

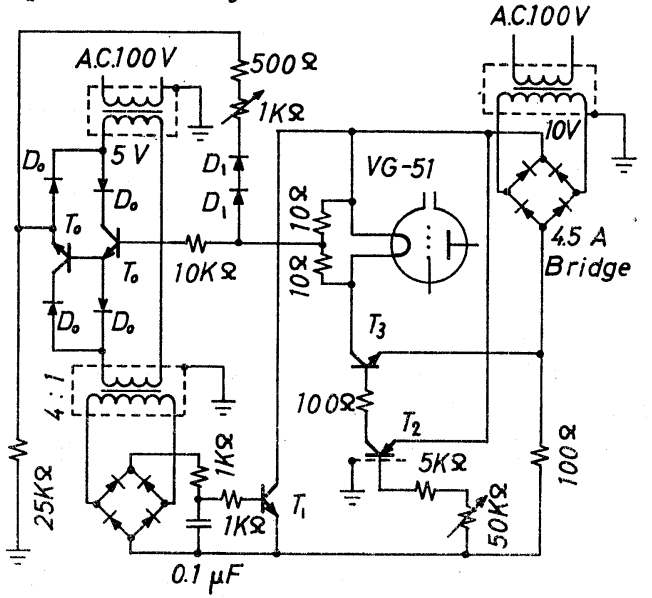

(a)

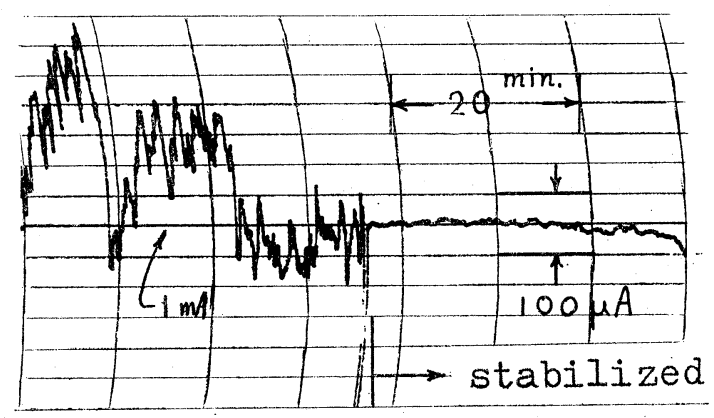

(b)

Fig. 6 (a) Practical circuit of regulator II. (b) An example of its dynamics.

てフィラメント加熱電流を制御する. 变成器 $\tau_{1}$ の捲線 比を $1: n$ とす机ば電子電流 $I_{b}$ とフィラメント加熱 
電流 $I_{c}$ の関係は

$$
I_{c}=\frac{\beta_{1} \cdot \beta_{2} \cdot \beta_{3}}{1+\frac{r_{1}}{r_{2}}} \cdot \frac{\beta_{0}}{n}\left(\frac{E_{0}}{r_{2} \cdot \beta_{1}} \cdot \frac{n}{B_{0}}-I_{b}\right) \cdots(2)
$$

でちえられるが；2.1項の場合と同じ理由で $I_{b}$ と $I_{c}$ の閥

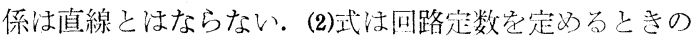
日安安与えるにとどまる。

Fig. 6(a) にこの方式による具体的な回路を，また（b) に真空度 $1 \times 10^{-5}$ Torr での動作例走示したＩ．の設定 は $\boldsymbol{r}_{1}$ を調節しておこなう。使用した電離真空計湔前項 と同じくVG-51 でする. 穴定化しないときの電子電

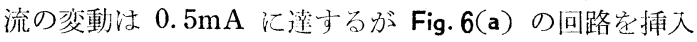

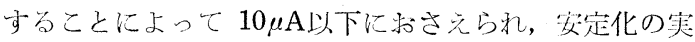
が上っていることがわかる。

\section{4 動作範囲}

陚作した安定化回路の $I_{b}-I_{c}$ 特性を調べれでその動作 範囲を知ることができる。電子電流 $I_{b}$ とフィラメント 加熱電流 $I_{c}$ の関係注(1)式（安定化回路 I の場合）市る いは(2)式（安定化回路II の場合）で表わせること注 2.1 項で述べたが，一般にトランジスターのエミッタ一接地 電流増巾率 $\beta$ が定でなく、コレクタ一電流の関数であ るために， $I_{b}$ 一 $I$ 特性は直線とはならない，実測による と Fig.7(a) に示したような曲線を描き， $I_{b}$ の值の大き なところで $I_{c}$ が飽和对る傾向が見られるが，安定化回 路の動作範囲はかなり広いと言える。(b-1)（b-2）はそ の測定用回路で電離真空計のヌィラメントの代りに整流 管 $5 Z 3$ のフィラメント岩使用していることと， $r_{b}$ 苍 供給するために補助の電源 $P$ r 在用いていることが，実

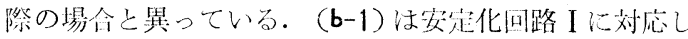
(b-2)注安定化问路Iに対応してい方。

\section{3. フィラメント保護回路}

電離真空計省低真空で使用すると酸化や多量のイオン 衝撃のためにフィラメントの消耗が激しく寿命が短くな るから, 真空装置の操作中に何らかの原因で真空度が悪 くなった場合には，そ机を検知して，フィラメントの加

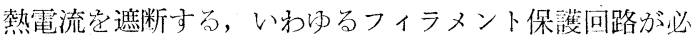
要である。

Fig. 8 は試作したフィラメント保護回路（网中の一点 鎖線で囲えだ部分)をFig.3(a) の電子電流安定化 回路 I と組合わせたものであって, 次のような動作順序でフ イラメントを保護する。つまり, 真空度が低下してフィ ラメントの表面温度が下がると電子電流が減少しようと するが, 電子電流安定化回路の安定化作用で, その減少 を補なうべくフィラメントの両端電圧が増加する。その

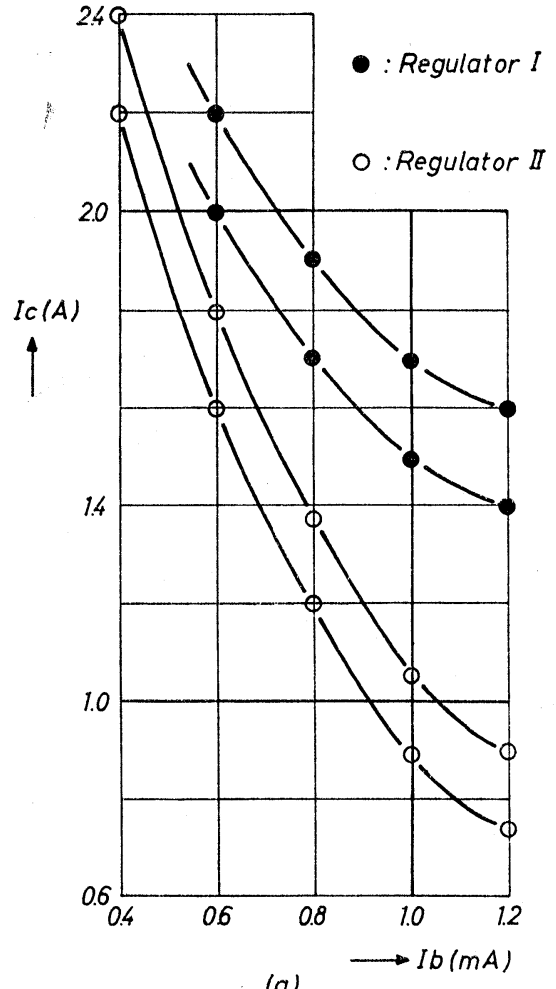

(a)

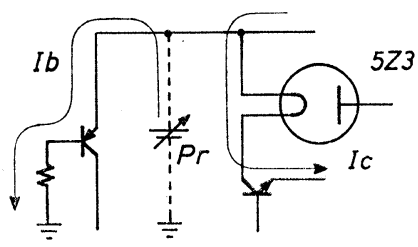

$(b-1)$

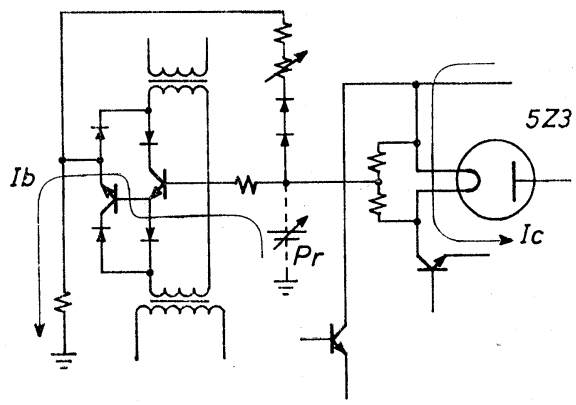

$(b-2)$

Fig. 7 (a) Dynamic range of these regulators. (b-1) Measuring circuit corresponding to regulator I . (b-2) Measuring circuit corresponding to regulator II. In both circuits, the filament of $5 Z 3$ is used instead of the filament of VG-51. 


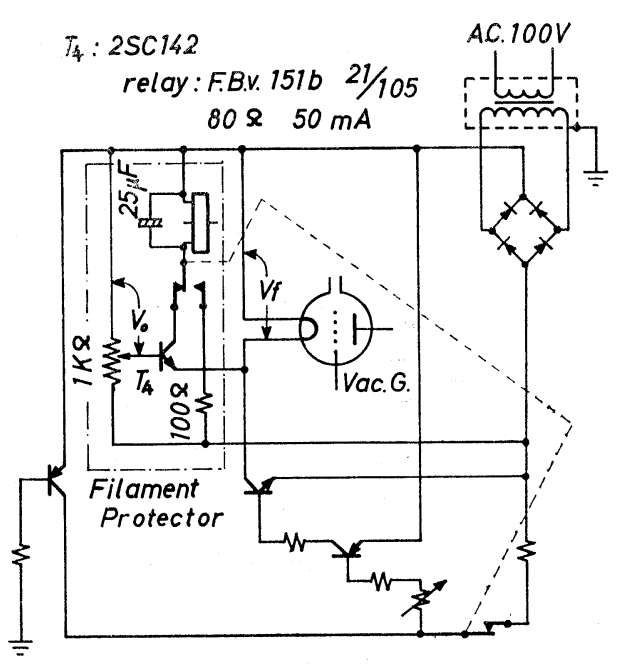

Fig, 8 Filament protector combined with regulator I.

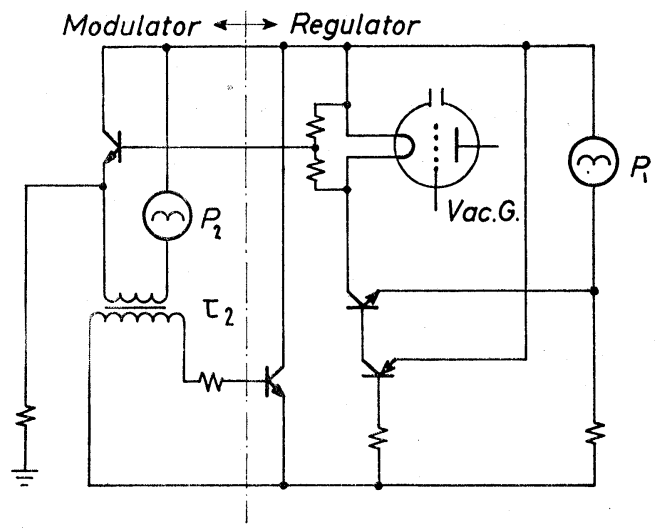

Fig. 9 More simplified circuit than regulator II. Both $P_{1}$ and $P_{2}$ are single-phase fullwave rectified power supplies. In the primary coil of transformer $\tau_{2}$, D-C current overlaps on A-C signals.

増加分をトランジスター $T_{4}$ で検知して, リレーを駆動 させてフィラメント加熱電流を遮断し，フィラメントを 保護する. リレーは不可逆的に動作するように結線して あるから,その後真空度が良くなっても, 電離真空計注 びセットしなおすまで回復しないようになっている.電 離真空計を動作させている状態では, 図中 $T_{4}$ のべース の電压 $V_{o}$ は, フィラメント加熱電圧 $V_{f}$ と同程度か, やや大きくしておく必要がある. $\left(V_{o}-V_{f}\right)$ の值の大き さ次第で保護回路の動作感度が定まる.なおフィラメン ト両端の電压增加分の検知には, トランジスター $T_{4}$ の 代りに適当な SCRを用いることもできる.

\section{4. むすび}

試作した回路についてその特徴などを列記すれ将次の ようになる。

（1）安定化回路 I は，问路の構成素子の数も少く， ᄂ たがって故障も少いと思われるが，真空度の指示に $2 \%$ 程度の誤差が入る。しかしこの程度の䛊差は真空度測定 上さしたる障㫪とはならないと考光られる。

（2）安定化回路 II は，回路 I の場合の上うな䛊爱は入 らないが，二種類の電源のほか变成器も必要であって， 構成がかなり複雑である. Fig. 9 注安定化回路II の变形 であって, 二個の全波整流電源 $\left(P_{1}, P_{2}\right)$ と変成器 $\tau_{2}$ 方必 要であるが，トランジスタ一，ダイオードなどはかなり 少くなって簡素化されている。しかしこの回路では，変 成器 $\tau_{2}$ に直流分が重畳しているので，それによる磁界 の飽和まで考慮して变成器学選ぶ必要がある.

（3）安定化回路 IおよびII はともに電源 $P_{1}, P_{2}$ のトラ ンスの線輸安，イオン電流測定用の增巾部の電源卜ラ ンスと同一コナーに捲くことができるから，七ット全体 が軽量となる。

（4）安定化回路 I およびII はともに抵抗 $r_{1}$ あるい湴 $r_{2}$ 学調節することによって $I_{b}$ 学任意の值に設定すると とができるが，同時に回路の感度 $\Delta I_{c} / \Delta I_{b}$ が变化してし まうのが欠点である。しかし実際にこの问路を使用する と，この欠点は少しも邪魔にならない。

（5）安定化回路 I およびII の動作範囲は，Ridenour一 Lampsonの回路のそれ ${ }^{6}$ に較べてかなり広いと言える.

（6）フィラメント保護回路は，従来の方式ではイオン 電流增巾器の後にシュミット回路をつけるために, イオ ン電流の測定に好ましくない影響を与えることも心配さ れるぶ，苚作したこの回路ではその心配はない。

（7）安定化回路 I とフィラメント保護回路の組合せ (Fig. 8) は, 構成の単純さ, 小型軽量および広動作範囲 という所定の要求をほぼ满しているものと見られる。

この実験をおこなうにあたり，数多くの重要な示陖を 与えてくださった, 現化学研究所大沼勇氏に心より感謝 いたします。

\section{[文 献]}

(1) Ridenour, L. N. and Lampson, C. W. : Rev. Sci. Instrum. 8 (1937) 162.

(2) King, A. H. : J. Sci. Instrum. 23 (1946) 85

(3) 中山勝矢 : 真空 8[4] (1965) 122.

(4) 近藤敏郎 : 実用新案出願公告 昭 $43-28636$

(5) 長井一敏：日本真空協会 第10回真空に関する逨 合講演会で講演 (1969).

(6) Steckelmacher, W. and Van der Meer, S. : J. Sci. Instrum. 27 (1950) 189. 